\title{
Hypothalamic involvement in premature aging laminopathies
}

\author{
Claudia Cavadas \\ From 1st French-Italian meeting on laminopathies and other nuclear envelope-related diseases \\ Marseille, France. 15-16 January 2015
}

Caloric restriction $(\mathrm{CR})$, the reduced intake of calories without malnutrition, extends lifespan of many organisms, from yeast to mammals, and delays the progression of age-related diseases. Evidence show that hypothalamus is a crucial brain region for the progress of whole-body aging [1] and the beneficial effects induced by $C R$ are regulated by nutrient-sensing neurons located in the hypothalamus [2]. Although CR's beneficial effects in delaying human aging are promising, its application for long periods is very difficult to maintain and not feasible to apply to fragile children with progeria. To overcome this problem, the induction of protective endogenous mechanisms, or pharmacological agents, could theoretically be used to mimic the beneficial effects of CR without its discomfort. Our group showed that hypothalamus of Zmpste24-/- mouse has lower levels of Neuropeptide Y, comparing to wild-type animals. Moreover, they showed that targeting the Neuropeptide Y system in hypothalamus, as a CR mimetic strategy, delays or reverts some ageing features of Zmpste24-/- mice. Further studies are needed to confirm this innovative approach and if it could be translational to progeria children.

Published: 11 November 2015

\section{References}

1. Zhang G, Li J, Purkayastha S, Tang Y, Zhang H, Yin Y, et al: Hypothalamic programming of systemic ageing involving IKK-beta, NF-kappaB and GnRH. Nature 2013, 497(7448):211-6.

2. Dacks PA, Moreno CL, Kim ES, Marcellino BK, Mobbs CV: Role of the hypothalamus in mediating protective effects of dietary restriction during aging. Frontiers in neuroendocrinology 2013, 34(2):95-106.
doi:10.1186/1750-1172-10-S2-06

Cite this article as: Cavadas: Hypothalamic involvement in premature aging laminopathies. Orphanet Journal of Rare Diseases 2015 10(Suppl 2): 06.

Correspondence: cavadas@ci.uc.pt

CNC - Center for Neuroscience and Cell Biology, University of Coimbra, Coimbra, Portugal, Faculty of Pharmacy, University of Coimbra, Coimbra, Portugal

Submit your next manuscript to BioMed Central and take full advantage of:

- Convenient online submission

- Thorough peer review

- No space constraints or color figure charges

- Immediate publication on acceptance

- Inclusion in PubMed, CAS, Scopus and Google Scholar

- Research which is freely available for redistribution

Submit your manuscript at www.biomedcentral.com/submit
() Biomed Central

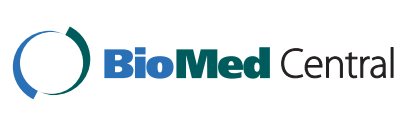

